\title{
Female Genital Mutilation (FGM) Practices and Its Health Implications among Parents in Ugep Urban of Yakurr Local Government Area of Cross River State, Nigeria
}

\author{
Iheanacho, Samuel B. C. (Ph.D) \\ Department of Human Kinetics and Health Edu. \\ University of Calabar, Calabar. \\ Ph: 08035505849; E-mail: drsbciheanacho@yahooo.com
}

Ubi Sylvanus (Ph.D)

College of Education, Akamkpa

Cross River State

Iheanacho, MaryJoan U.

Department of Business Management

University of Calabar, Calabar

Rosemary Nkang

Dept. of Human Kinetics and Health Education

University of Calabar, Calabar

Received: July 10, 2013 Accepted: August 29, 2013 DOI: 10.5296/jpag.v3i3.4380

\begin{abstract}
The study was undertaken to find out whether or not the practice of Female Genital Mutilation (FGM) still prevails and whether parents who still subject their daughter to this obnoxious practice are conscious of the health consequences. A sample population of four hundred (400) male and female parents was used subjects for the study. These subjects were selected using stratified random sampling technique. A questionnaire developed by the researchers was used as instrument for data collection while the research design was survey. The research tool was validated by health education experts in the department of Human
\end{abstract}


kinetics and health education, University of Calabar and the test - retest reliability was 0.86 . The data collected was analyzed using frequency count. The findings revealed that no type of FGM exists in Ugep and parents are not compelled by any reason to circumcise their daughters. Parents did not differ significantly in the awareness of the health implications of FGM. Among the recommendations proffered was that FGM prevention programme should reinforce the current campaign against FGM by placing emphasis and increasing awareness of the dangers of FGM.

Keywords: Female, Genital, Mutilation

\section{Introduction}

Female circumcision according to Anderson, (1989) is a 2,500 - year old tradition still practiced in several countries, most especially in the middle belt of Africa. Many reasons have been given for the practice of Female Genital Mutilation (FGM). According to Hosken (1979), they include - prevention of immorality; preparing females for marriage; to ensure cleanliness; to prevent labia hypertrophy; to improve fertility; to give more pleasure to the husband; for religious rights and obligations.

WHO (1997) reported that Female Genital Mutilation is a practice which involves cutting off part or whole of a clitoris and some other parts of her sex organs whether for cultural or any other non-therapeutic reasons. In Ugep, this practice goes beyond the cutting-off, of the clitoris, as it serves as a cultural process through which a young girl prepares for the responsibilities of womanhood (Ministry of Information Youth Sports \& Culture, (1998).

In every community in Cross River State, Nigeria, elaborate arrangement exist where young girls are tutored and groomed for this cultural process. This is particularly true of girls who, because of their expected role as house wives and mothers, form the backbone of any successful union.

On attaining the age of puberty a young girl is qualified to enter the "Kukpel House" literally known as "Fattening Room". This is a room or apartment prepared in a girls father's compound. In some communities the house of the girl's suitor is used. It is usually provided with materials that enable the girl learns traditional crafts like weaving, sewing, cookery, pottery etc.

One of the pre-requisite for initiation into this institution was that the girl is a virgin. Loss of virginity could mean loss of face for her family, and embarrassment for herself. In addition, clitoridectomy of the initiate was performed before the girl entered into confinement. During the period of confinement the girl is attended to by a lady - in - waiting who sees to all her needs. Every effort is made to ensure that the girl emerges from the fattening room more beautiful and more attractive than she was before. She is taught how to prepare varies kinds of dishes, simple home - crafts like weaving, sewing and knitting as well as house - keeping. 


\section{Macrothink}

The training also includes learning to be patient with a husband in time of anger, and how to console him in time of adversity. Chastity is one of the qualities expected of a good woman and this is stressed during the course of training. It is also during this period of confinement that the girl is expected to know the history, and folk-lore of the society to which she belongs. It was strongly believed that a girl who did not pass through this traditional process of education was not ripe enough to face the challenges of womanhood. For this reason any woman who is uncircumcised is not only subjected to frequent embarrassing innuendoes from other women but remains a social outcast for life.

One aspect of this cultural practice that motivated this study is the practice clitoridectomy of the initiate. Over the years the issue of Female Genital Mutilation has become a growing concern among women. A lot has been said in recent times condemning this practice but for all the cries about the ills of this practice people still believe that the risk of not doing it are too severe. Female circumcision in Ugep is a custom shrouded in tradition that, it has become a part of the people's lives. Perhaps due to ignorance and in an attempt to hold onto their cultural practices and heritage the health hazards of this practice are not taking into consideration.

The purpose of this study therefore, was to investigate various types of this practice in Ugep; the main reasons for this obnoxious practice and the level of awareness of its health implications.

\section{Research Questions}

The following research questions were therefore postulated to guide the study:

i) How does culture compel you to circumcise your female children?

ii) What are the reasons for female genital mutilation (FGM) practices in Ugep?

iii) What is the level of awareness of the health hazards of female genital mutilation?

iv) To what extend does female genital mutilation facilitate the spread of HIV/AIDS?

\section{Method}

The subjects used for this study were four hundred (400) parents from two hundred household made up of male and female parents. These subjects were randomly selected from the four council wards of Ugep urban in Yakurr Local Government Area of Cross River State. The distribution of respondents is shown in Table 1: 


\section{Macrothink

Table 1: Distribution of Respondents

\begin{tabular}{|l|l|l|}
\hline Council Ward & Household & $\begin{array}{l}\text { Total No. of Parents } \\
\text { (Male \& Female) }\end{array}$ \\
\hline Ijom & 50 & 100 \\
\hline Ijiman & 50 & 100 \\
\hline Bikobiko & 50 & 100 \\
\hline Ikpakapit & 50 & 100 \\
\hline Total & $\mathbf{2 0 0}$ & $\mathbf{4 0 0}$ \\
\hline
\end{tabular}

\section{Instrument}

The instrument used for this study was a questionnaire designed by the researchers on the practice of female genital mutilation and its health implications among parents in Ugep urban. The instrument elicited information on the practice and awareness of the health implications of female genital mutilation. The items were based on a 4 - point likert type scale of strongly agree, agree, disagree and strongly disagree. The instrument was validated by experts in this Field of Study. The reliability co-efficient was found to be 0.86 using the split-half reliability estimate.

\section{Data Collection and Analysis}

A letter of permission to undertake this study was sent to "Obol Lopon" of Ugep and paramount ruler of Yakurr Local Government Area of Cross River State. After permission was granted the research team was introduced to the council ward chiefs. In each ward a facilitator was selected. The criteria for selection emphasized knowledge of the community, ability to read and write English language and ability to understand and speak Yakurr language. The role of the facilitators was to assist in orienting the research team to each council ward, interpret each item on the questionnaire and fill the option of a parent who may not be able to read or write. Every household selected for the study was visited so that all the questionnaires were filled and collected on the spot.

Descriptive statistics of frequency and percentages were used to analyse the data for the study. 
Table 2: Frequency and percentage distribution of respondent for the types of female genital mutilation practice.

\begin{tabular}{|c|c|c|c|c|}
\hline \multirow[t]{2}{*}{ Item } & \multicolumn{4}{|c|}{ No. of Respondent Household 400} \\
\hline & Agreed & $\%$ & Disagreed & $\%$ \\
\hline 1. Total excision of part of the clitoris. & 0 & 0 & 400 & 100 \\
\hline 2. Excision of part of the clitoris. & 0 & 0 & 400 & 100 \\
\hline $\begin{array}{l}\text { 3. Excision of part of the external } \\
\text { genitalia. }\end{array}$ & 0 & 0 & 400 & 100 \\
\hline 4. Excision of all the external genitalia. & 0 & 0 & 400 & 100 \\
\hline 5. Pricking of the clitoris & 5 & 1.3 & 395 & 98.7 \\
\hline
\end{tabular}

Table 2 presents the frequency and percentage distribution of respondent for the type of female genital practiced. The result revealed that no respondent, representing $0 \%$ agreed on any of these items, such as total excision of the clitoris; excision of parts of the clitoris; excision of part of the external genitalia. In each of these items all 400(100\%) respondents disagreed. The statement that pricking of the clitoris was a type of FGM practiced, $5(1.3 \%)$ respondents agreed, while $98.7 \%$ disagreed. 
Table 3: Frequency and percentage responses on reasons for the practice of female genital mutilation by parents.

\begin{tabular}{|c|c|c|c|c|}
\hline \multirow[t]{2}{*}{ Item } & \multicolumn{4}{|c|}{ No. of Respondent 400} \\
\hline & Agreed & $\%$ & Disagreed & $\%$ \\
\hline $\begin{array}{l}\text { 1. To increase fertility of the } \\
\text { woman. }\end{array}$ & 48 & 22 & 352 & 88 \\
\hline 2. For moral purposes. & 30 & 7.3 & 370 & 92.5 \\
\hline 3. As prerequisite for marriage. & 60 & 15 & 340 & 85 \\
\hline 4. To avoid promiscuity. & 75 & 18.75 & 340 & 81.5 \\
\hline $\begin{array}{l}\text { 5. A circumcised wife is more } \\
\text { faithful and a better housewife. }\end{array}$ & 65 & 16.25 & 335 & 83.8 \\
\hline $\begin{array}{l}\text { 6. To ensure the cleanliness of the } \\
\text { vagina. }\end{array}$ & 53 & 13.5 & 247 & 86.8 \\
\hline $\begin{array}{l}\text { 7. The risk of not doing it are too } \\
\text { severe. }\end{array}$ & 22 & 5.5 & 378 & 94.5 \\
\hline 8. All of the above. & 10 & 2.5 & 390 & 97.5 \\
\hline
\end{tabular}

The result on table 3 shows that $48(22 \%)$ of the respondents agreed with the statement that FGM was practiced to increase the fertility of the woman, while 352(88\%) disagreed with this statement. On the statement that FGM was practiced for religious purposes, the result revealed that 30(7.3\%) respondents agreed with the statement while 379(92.5\%) disagreed. From the result it was also noted that 60(15\%) respondents agreed that FGM was a prerequisite for marriage while $340(85 \%)$ disagreed. In the same vein, $75(18.75 \%)$ respondents agreed that FGM was practiced to avoid promiscuity while $325(81.5 \%)$ disagreed. Also, 65(16.25\%) of the respondents agreed with the statement that a circumcised wife is more faithful and a better housewife, while 335(83.8\%) disagreed. The statement that 


\section{Macrothink}

FGM was done to ensure the cleanliness of the vagina, 53(13.5\%) respondents agreed with this statement, while $247(86.8 \%)$ disagreed. The response to item 7 which said that "the risk of not doing it are too severe", 22(5.5\%) respondents agreed while 378(94.5\%) disagreed. Those who agreed to all the items stated on table 3 were $10(2.5 \%)$ while $390(97.5 \%)$ disagreed.

For instance, the statement on whether FGM was practiced for moral purposes, the high percentage of disagreed response indicated by respondent leaves no evidence to prove that the circumcised woman is morally upright than the uncircumcised.

Table 4: Frequency and percentage distribution of respondent on the level of awareness of the health hazards of FGM.

\begin{tabular}{|c|c|c|c|c|}
\hline \multirow[t]{2}{*}{ Item } & \multicolumn{4}{|c|}{ No. of Respondent 400} \\
\hline & Agreed & $\%$ & Disagreed & $\%$ \\
\hline $\begin{array}{l}\text { 1. Risk of hemorrhage during child } \\
\text { birth. }\end{array}$ & 380 & 95 & 20 & 5 \\
\hline $\begin{array}{l}\text { 2. Fear, anxiety, prolong pain and mental } \\
\text { distress. }\end{array}$ & 350 & 87.5 & 50 & 12.5 \\
\hline 3. Death resulting from excess bleeding. & 320 & 80 & 80 & 20 \\
\hline 4. Chronic pelvic infection. & 280 & 70 & 120 & 30 \\
\hline $\begin{array}{l}\text { 5. Infertility resulting from fallopian } \\
\text { tube infection. }\end{array}$ & 275 & 68.8 & 125 & 31.2 \\
\hline $\begin{array}{l}\text { 6. Obstruction during labour resulting from } \\
\text { the narrowing of the vaginal canal. }\end{array}$ & 255 & 62.5 & 145 & 36.5 \\
\hline 7. Facilitates the spread of HIV/AIDS & 243 & 60.8 & 157 & 39.3 \\
\hline
\end{tabular}

In table 4 the frequency and percentage distribution of respondents on the level of awareness of the health hazards of FGM was presented. The health hazard mostly indicated by 
respondents was risk of hemorrhage during the time of circumcision with $380(95 \%)$ agreed and $20(5 \%)$ disagreed responses.

This is followed by fear, anxiety, prolonged pain and mental distress with 350(87.5\%) agreed and 50(12.5\%) disagreed responses. Death resulting from excess bleeding during circumcision came next with $320(80 \%)$ agreed and $80(20 \%)$ disagreed responses. The items concerning chronic pelvic infection had $280(70 \%)$ agreed response respectively, while the disagreed response stood at $120(30 \%)$. Infertility resulting from fallopian tube infection was 275(68.8) agreed while 125(31.2\%) disagreed. The next health hazard was the narrowness of the vaginal canal that could cause obstruction during labour with 255(62.5\%) agreed and $145(36.5 \%)$ disagreed responses. The last item was spread of HIV/AIDS with $243(60.8 \%)$ agreed and 157(39.3\%) disagreed responses.

\section{Discussion}

This study sought to investigate FGM practices among parents and its health implications in Ugep urban in Cross River State, Nigeria. The analysis on table 2 revealed that FGM is no more practiced by parents. This was shown in the response to the type of FGM currently practiced in Africa as identified by World Health Organization (1995). WHO identified four types of FGM currently practiced to include excision of the prepuce, excision of the clitoris and prepuce (clitoridectomy), excision of part or all the external genitalia and clitorial prickling. The high percentage of negative response of $100 \%$ indicated by respondents revealed the extinction of the cultural practice in Ugep. With this result it was evident that parents are not associated with any of these type of FGM practices and are not culturally bound to circumcise their daughters.

Table 3 presents the analysis of the reasons for FGM practices in Ugep. Several reasons were highlighted for FGM practices which are in line with that of Hosken (1979) as earlier stated. The high percentage of $98 \%$ disagreed responses indicated by respondents revealed that parents are not compelled by any of these reasons to circumcise their daughters. For instance, the statement on whether FGM was practiced for moral purposes, the high percentage of disagreed response indicated by respondents leaves no evidence to prove that the circumcised woman is morally upright than the uncircumcised. The assertion is in line with WHO (1995) that reported that religion (moral) is central to the live of many women and this is usually manipulated to control their sexuality and that FGM is not required by any religion; equally, there is no scientific evidence that women who have been genitally mutilated are more faithful or better wives than those who have not. The analysis in table 4 showed the awareness level of respondents on the health hazards of FGM.

The findings revealed that the health related problems arising from FGM which majority of the respondents indicated included the risk of hemorrhage during child birth (95\%); fear, anxiety, prolong pain and mental distress $(87.5 \%)$ and health resulting from excessive bleeding (80\%). This findings conforms with Kun (1997) who stated that mutilated women are reported to be at greater risk of hemorrhage at child birth because of obstructed labour and tearing of vaginal and perinial scar tissue. The result of fear and anxiety supports earlier study of Akinwusi and Ogundele (2004), who identified the immediate and psychological 


\section{Macrothink}

implications to include fear, anxiety, prolonged pain, mental distress, bitterness, sense of incompleteness, loss of self esteem, withdrawal, sleep, mood disorder, anger, depression, long-lasting instability, several acts of deception and intimidation. The results on pelvic $(70 \%)$ and fallopian tube (68.8\%) infection, showed that parents were highly aware of these health hazards. Ogundele affirmed that acute and chronic pelvic infection could be carried at the time of circumcision, also from retention of urine and vaginal secretions because of infections such as cystitis vaginitis and cervicits.

With regards to the spread of HIV/AIDS, the findings revealed that $60.8 \%$ of the respondents supported the fact that FGM can facilitate the spread of AIDS through the use of same crude and unsterilized instrument. This assertion supports that of Al-Adeeb, (1997) that use of the same instrument on many females without sterilization can cause the spread of HIV/AIDS.

In the same vein Sylvester (2004) opined that piercing objects should be sterilized after use because use of unsterilized surgical instruments increase chances of being infected.

\section{Conclusion}

The result of the study tends to suggest that in all the focused population of the studies, parents were adequately aware of the health risk posed by FGM. Reasons for FGM are no more in vogue; therefore parents are not compelled any more to circumcise their daughters. Finally, none of the types of FGM practices identified exist in Ugep.

\section{Recommendations}

1. FGM prevention programme should reinforce current campaign against its practices by placing emphasis and increasing awareness of the dangers involved.

2. FGM education should be incorporated into the school subjects; the content should include simple basic sex education and health education strategies for its prevention.

3. Women should be constantly informed on the risk of FGM and be aware of their right to oppose and reject this obnoxious practice.

4. The WHO (1996) has continually and unequivocally advised that FGM must not be institutionalized nor should any form of FGM be performed by any health professional in any setting, including, hospitals or other health establishments. This advice will be strengthened if the government of Nigeria enacts a law against further practice of FGM in all part of the country.

5. The States and National Assemble of the country should enact a law banning the practice in all Local Government Council in Nigeria. 


\section{Macrothink \\ Journal of Public Administration and Governance \\ ISSN 2161-7104 \\ 2013, Vol. 3, No. 3}

\section{Reference}

Akinwusi, A. T. \& Ogundele, B. O. (2004). Creating awareness of psycho-physiological implication of female mutilation among secondary school adolescents through three modes of instruction. Nigeria School Health Journal, $16(1 \& 2)$, pp.145 - 151.

Al-Adeeb, A. (1994). Female genital mutilation. A human right information pack. Geneva.

Anderson, B. L. (1989). How to eradicated circumcision of girls'. A study of efforts in Egypt, Kenya and Mali.

Hosken, P. F. (1979). The Hosken report. Genital and sexual mutilation in females ( ${ }^{\text {nd }}$ ed) Washington USA women International Network (WIN).

Kun, F. (1997). Obstetric problems among female genital mutilation. Internal Journal of Gyneoclogy and Obstetrics. 9 p.152.

Ministry of information youth sports and culture (1998). Heritage magazine of Cross River State - Nigeria Vol.2 p.8 - 9 .

Sylvester, A. (2004). Quality health education for HIV/AIDS prevention in Nigeria. Nigeria School Health Journal, 16 (1\&2), pp-125 - 129.

World Health Organization (1995). Traditional practices affecting women's health. An overview, Geneva.

World Health Organization (1996). Female genital mutilation. An overview Geneva.

World Health Organization (1997). Female genital mutilation report of a technical working group. Geneva. 